\title{
Fighting Against the Wrong Argument That the Communist Party of Vietnam Should Not Consider Marxism-Leninism and Ho Chi Minh's Thought the Ideological Foundation
}

\author{
Ngoc Loi Pham \\ Faculty of Public Relations and Social Work, Ho Chi Minh City Cadre Academy, Ho Chi Minh City, Vietnam
}

Email address:

phamngocloi728@gmail.com

\section{To cite this article:}

Ngoc Loi Pham. Fighting Against the Wrong Argument That the Communist Party of Vietnam Should Not Consider Marxism-Leninism and Ho Chi Minh's Thought the Ideological Foundation. Advances in Sciences and Humanities. Vol. 6, No. 3, 2020, pp. 89-93. doi: $10.11648 /$ j.ash.20200603.12

Received: September 7, 2020; Accepted: September 28, 2020; Published: October 7, 2020

\begin{abstract}
This article aims to analyze to fight against the wrong claims of the hostile forces of Vietnam revolution is that Marxism- Leninism is outdated and the Communist Party of Vietnam should not consider Marxism-Leninism and Chi Minh's thought as its ideological foundation. First, they claim that Marxism - Leninism was born in the economic and social context of the 19th and early 20th centuries, making it unsuitable for the contemporary situation. Second, they state that the collapse of socialism in the Soviet Union and Eastern Europe proved that Marxist - Leninist socialism was mistaken and obsolete. Third, according to them, the mistakes and difficulties involved in building a socialist country originated from Marxism - Leninism. In this paper, the author has used scientific research methods such as analysis and synthesis, interpretation and induction, abstraction and generalization, logical and historical comparison to criticize the wrong claims of the hostile forces. The research has come into 3 conclusions. The first is Marxism-Leninism is a scientific and legal theory; the second is the collapse of socialism in the Soviet Union and Eastern European countries was only the breakdown of a model; the third is the selection and application of Marxism-Leninism and Ho Chi Minh's Thought in Vietnam as the ideological foundation is a right thing. Therefore, the application of Marxism-Leninism into the cause of national liberation and building socialism in Vietnam is a right choice of the Communist Party of Vietnam.
\end{abstract}

Keywords: Marxism-Leninism, Ho Chi Minh's Thought, Fight Against the Wrong Argument,

The Communist Party of Vietnam

\section{Introduction}

In recent times, the claims of the hostile forces often used to attack the ideology of the Communist Party of Vietnam are: Marxism-Leninism is outdated and the Communist Party of Vietnam should separate Marxism-Leninism and Ho Chi Minh's thought. The hostile forces claim that the socialism collapsed in the most important part, sooner or later countries following this regime will also collapse and only capitalism is the "last stage of history" and eternal. In their view, there was no Ho Chi Minh thought and if it did, it was also the "old communist ideology". They denied the merits and great contributions of President Ho Chi Minh to the Vietnamese revolution and the revolutions of the people in the world. They often reversed his arguments. To achieve their goal, they mixed verified objective documents with false and misleading claims to gain confidence from the reader.

This paper aims to criticize all the wrong claims of hostile forces and affirms that Marxism- Leninism and Ho Chi Minh's thought are never outdated and the Communist Party of Vietnam should not consider Marxism-Leninism and Ho Chi Minh's thought the ideological foundation. According to Le Quy Trinh, “the argument for separating Ho Chi Minh's ideology from Marxism-Leninism is a malicious trick by the hostile forces in a bid to distort and deny our Party's ideological ground" [1]. 


\section{Defending the Correctness of Marxism-Leninism and Ho Chi Minh's Thought}

First of all, the hostile forces claim that Ho Chi Minh's thought is outdated since President Ho Chi Minh took Marxism-Leninism as the foundation for the Vietnamese revolution, but Marxism - Leninism was born in the economic and social situation of the 19th and early 20th centuries, making it unsuitable for the contemporary situation. Secondly, realistic socialism was built on the theories of Karl Marx, Friedrich Engels, and V. I. Lenin in the former Soviet Union and collapsed Eastern European countries. The collapse proves that their theories were faulty; therefore, the Vietnamese revolution, which equipped it with that theory, was even more wrong. Thirdly, a series of mistakes and shortcomings of the countries following the socialist path, including our country, proves that the theory of socialism is false and out of date, so we must soon give up and choose a new suitable theory to develop the country. It can be affirmed that the above claims are false and have no scientific basis, that is, a blatant distortion of the truth. Because Marxism-Leninism is a scientific theory of movement and development recognized by the whole world and President Ho Chi Minh was honored by UNESCO as "Vietnamese hero of national liberation and great man of culture" at the 24th Session of the General Assembly of UNESCO in Paris, from October 20 to November 20, 1987, approving Resolution 24C / 18.65 on the centenary of the birth of President Ho Chi Minh as Vietnamese hero of national liberation and a great man of culture in 1990 [2].

Regarding the first reason, it is true that MarxismLeninism was born in the mid-nineteenth century when conflict within capitalism was heating up and capitalism was exploiting the working class. K. Marx and F. Engels inherited the achievements of the former research, selectively absorbing all the quintessential values of the human thought development process. For the first time in the history of human thought, K. Marx and F. Engels made the historical discovery of the law of movement in human society, which describes the dialectic relationship between forces production volume and production relationship. This was the basis for $\mathrm{K}$. Marx and F. Engels to predict the inevitability of mankind to progress to communism through a transition period of socialism. V. I. Lenin was the one who continued to develop the thought of C. Marx and F. Engels in the late nineteenth century and early twentieth century under the new conditions when capitalism turned to imperialism. He introduced an idea of the victory of the proletariat revolution in some capitalist countries, building a new type of Marxist party which belong to the working class, organizing the revolution and applying the Marxism-Leninism to analyze and solve a series of problems in the process of building socialism in the Soviet Union. President Ho Chi Minh pointed out that Lenin was respected in both the East and the West. He stated, "'If the Western proletariat sees Lenin as a leader, and a teacher, then the Eastern peoples consider Lenin an even greater, more noble person" [3]. Lenin's genius and revolutionary morality greatly influenced the peoples of Asia, making the hearts and minds of the Asian people irresistible to him. President Ho Chi Minh affirmed that the Vietnamese revolution followed Lenin's instructions. He said, "While Lenin was alive, he was our father, teacher, comrade, and counselor. Today, he is a bright star pointing the way for us to go to the social revolution" [4].

From a patriot who absorbed Marxism-Leninism, especially Lenin's theses on the national and colonial question, President Ho Chi Minh's thought on national salvation and liberation had qualitative changes [5]. In the mid-twentieth century, Ho Chi Minh creatively applied Marxism - Leninism to Vietnamese realities to defeat imperial countries and win national independence, protecting each sacred piece of land and leading the Vietnamese revolution from victory to victory.

President Ho Chi Minh was born and grew up in turbulent period of the country. At that time, many uprisings and struggles for national independence and reunification all failed in turn, our people's nation-saving movement faced a deep crisis of direction. With a burning desire for independence and freedom for the country, he traveled around the five continents, working, studying and observing theory and experience of the typical revolutions in the world. He understood clearly the source of the suffering of the working people was the oppression and exploitation of imperial capitalism and forming a clear class consciousness. With the advent of the Communist Party of Vietnam in 1930, together with the first political Platform of the Party, the Vietnamese revolutionary line was basically formed, and the correct way to save our country was identified. This not only cleared the impasse in the way of national liberation, but also correctly resolved key issues of the Vietnamese revolution. Under the leadership of the Party, headed by leader Ho Chi Minh, the Vietnamese people united into a bloc, bringing into full play the strength of the whole nation, making the victory of the August Revolution in 1945, overthrowing the colonialism, feudalism and founding the Democratic Republic of Vietnam - the first People's Democratic State in Southeast Asia [6]. In the Declaration of Independence read on September 2, 1945, President Ho Chi Minh formally proclaimed to the nation, his people and the whole world: "Vietnam has the right to enjoy freedom and independence. And in fact, it has become a free and independent country". This is a work that has become an extremely important document, an epic written with all the enthusiasm, wisdom, human thought and will of a person, representing for a nation that is fighting and willing to sacrifice for its independence and freedom [7].

Immediately after winning our independence, our fledgling revolutionary government faced a very difficult situation, President Ho Chi Minh and the whole Party wisely proposed the right path to take the revolutionary to overcome challenges, protecting the Party and maintaining the revolutionary government. On the basis of the "all-people", 
"comprehensive", "long-term" resistance war, "relying on our own strength" [8] to promote the tradition of unity and patriotism of the entire nation, President Ho Chi Minh and our Party led the people in turn to defeat all the enemy's invasion plans, especially the victory of the 1953-1954 Winter-Spring campaign and "Dien Bien Phu Victory", forcing French colonialist to sign Geneva Agreement in 1954 to end the war of invasion in Vietnam.

With the spirit of "We would rather sacrifice everything. We are determined not to lose our country and not be enslaved", "nothing is more precious than independence and freedom", following the Testament of President Ho Chi Minh, on the basis of the Party's right and creative lines, combining the strength of the entire nation with the power of the times, our army and people have in turn defeated the war strategies of the American imperialism to liberate the South, completing the national liberation revolution, building and bringing the country to socialism. Following the revolutionary path outlined by President Ho Chi Minh, in any circumstances, our Party always firmly aims at national independence associated with socialism, applying creatively Marxism-Leninism and Ho Chi Minh's thought, constantly improving prestige, leadership capacity and fighting strength to successfully implement national renewal and international integration. The country's great and meaningful achievements after nearly 35 years of renovation and international integration are vivid evidence confirming the right and wise leadership of our Party, affirming the correctness of the Vietnamese revolutionary line outlined by President Ho Chi Minh. Being the founder of the Party, Front, Army, as well as the founder of the Democratic Republic of Vietnam, for nearly a quarter of a century, the top leader of the State, President Ho Chi Minh has left a great heritage on the organization and building a new democratic state in our country. Ho Chi Minh's thought on building the state of the people, by the people, for the people is the creative application of the Marxist-Leninist doctrine of the state, selecting and inheriting the quintessence in state construction in the history of the nation and mankind [9]. All the above realities have proved that Marxism-Leninism and Ho Chi Minh's thought are correct; therefore, there is no reason to say that they are outdated.

It can be affirmed that Marxism-Leninism cannot be outdated. Those who do not see the movement and social development of Marxism and Leninism and Ho Chi Minh's thought are obsolete people. They deliberately fail to see the scientific and humanistic nature of Marxism-Leninism and Ho Chi Minh's thought. The rebellious forces deliberately distorted Marxism-Leninism and Ho Chi Minh Thought for a political defending for capitalism and the interests of the capitalist group, maintaining a regime of exploiting workers.

Second, is the collapse of socialism in the Soviet Union and Eastern Europe proof that Marxist - Leninist socialism is mistaken and obsolete? Did socialism collapse because of erroneous theories? This lead to the view that socialism collapsed in the Soviet Union and Eastern European countries, Vietnam should not and cannot attach the goal of national independence and socialism. At present, they are bluntly insisting: The Communist Party of Vietnam must voluntarily and actively change the Platform, give up the wrong way of building socialism, completely turn to the nationalism and democracy, the focus is the transformation of political institutions. These views show their superficial and metaphysical side. The collapse of the socialist regime in the Soviet Union and Eastern European countries in the late 1980s and early 1990s was a major political earthquake of the twentieth century. It had a great influence not only on the socialist world but also on the capitalist one.

We need to have a comprehensive viewpoint, first of all, acknowledging that the real socialism model has in fact brought about dramatic changes in Soviet Union, Eastern European countries and a series of countries around the world. It has brought a good life to a great part of humanity. It has created a force that is strong enough to mobilize human strength and wealth to defeat even the great forces of the capitalism in World War I as well as brutal fascist army in World War II. Socialism has encouraged and promoted the struggle for freedom, democracy, peace, and national liberation all over the earth. A series of oppressed peoples gained independence, freedom under the influence and carefree help of the Soviet-led socialist countries. The struggle of working people all over the world is a driving force, forcing the capitalist and imperial forces to recognize the freedom and independence of the peoples in the colonial countries. On the other hand, they create pressure to force capitalist forces to implement social reforms improving the lives of working people in the country.

The collapse of the Soviet Union and Eastern European countries was the collapse of a socialist-building model, not the collapse of socialism in general and Marxist-Leninism. The collapse of the model of real socialism in the Soviet Union and Eastern Europe was a painful lesson not only for the communists, but also for the progressive humanity [10]. It is a result of conservatism and not looking directly at the reality. They were too slow in having awareness, reforming policies as well as taking necessary solutions to solve problems arising from practice. That was also the mistake of the communists in the Soviet Union and the former socialist countries due to not properly perceiving the basic principles of the dialectics and specific historical view in MarxismLeninism in the process of leading the socialist revolution. Besides the subjective reasons mentioned above, there was another direct cause, which was the conspiracy and tricks of the "peaceful evolution" of the hostile imperialist forces. After World War II, they intensified the arms race. While the Soviet leaders advocated peace, the imperialist forces promoted the arms race, proposing a "peaceful evolution" strategy to eliminate socialism without war and gunfire. The Soviet Union and many other countries fell into this trap without self-discovery.

These examples prove that the collapse of socialism in the Soviet Union and other countries does not mean that Marxist Leninist theory on socialism is erroneous or outdated and Vietnam should change the way President Ho Chi Minh and 
The Communist Party of Vietnam has chosen. The predominant of capitalism is an illusion. In practice, capitalism is currently facing serious challenges. It is the conflict of benefits that is part of the nature of capitalism, causes indispensable separation among the so-called strong allies.

Third, do the mistakes and difficulties involved in constructing a socialist society originate from Marxism Leninism?

It must be said that from the day of its establishment, President Ho Chi Minh and our Party have proposed the policy "implementing national liberation revolution to advance to the socialist revolution" [11]. The path of national independence associated with socialism was set out from the fact that our country at that time was a French colony, also stemming from the trend of regular development of the new era after the October Revolution was to move to socialism. Over the past 90 years, the development stages of the Vietnamese revolution and the achievements of great and historical significance have proved the correctness of this path. We cannot abandon this correct path due to the collapse of Soviet Union and Western Europe. In the construction of socialism, Vietnam has learned from the experiences of the Soviet Union and its former socialist countries, but we have not copied the original model exactly. The model of building socialism in Vietnam is not the model of the Soviet Union, because the basic difference is that the former came to socialism form the base of capitalist regime and the latter from the revolution of national independence. President Ho Chi Minh once said: "I had only the ultimate desire to make our country completely independent, our people completely free, and our compatriots have means of subsistence and schooling" [12]. President Ho Chi Minh and The Communist Party of Vietnam have defined the values of socialist Vietnam include "rich people, strong country, democracy, justice, civilization". Confusing the socialist building model in Vietnam with the Soviet's one is a big mistake.

On the other hand, our Party highly appreciates and respects the principle of self-criticism and criticism, never concealing mistakes, limitations and difficulties in the process of building socialism in Vietnam. In the Political Report of the Party Central Committee presented at the XII Congress clearly indicated: "economic growth is slower that of the previous five years, the set goals have not been achieved; and productivity, quality, effectiveness, and competitive ability are all low. Officials' degradation of political thought, morality, and lifestyle, as well as corruption and wastefulness, has not been kept in check. Socialist democracy and national strength and solidarity have not been brought into full play. Laws and regulations are not strict enough..." [13]. Our Party, looking directly at the truth, clearly stating and assessing the truth, admitted that the above situation was caused by both objective and subjective reasons. But the most direct and decisive causes are the subjective ones. These include limitations within evaluation, prediction, theory research, reality summarizing, leadership, and the management of executive committees and governments. Since building socialism is an extremely difficult, complex, scientific task that requires time, great resources, mistakes are unavoidable. We embarked on building socialism from an outdated agricultural country, severely damaged after a fierce war that lasted for 30 years. The biggest difficulty, first of all, was not from the lack of wealth and resources, but mostly in the viewpoint and style of the agricultural culture. We also had to face challenges from many enemies trying to sabotage us. Under these circumstances, the achievements that our country achieved are especially significant. We have maintained a high GDP growth rate of more than $6.5 \%$ per year during the 30 years of implementing the Doi Moi policy. GDP in 2018 increased by $7.08 \%$, the highest growth rate since 2008 , confirming the timeliness and efficiency of the solutions promulgated by the Government and drastically directed at all levels, sectors, localities together with our great efforts. In the overall growth of the whole economy, the agriculture, forestry and fishery sector increased by $3.76 \%$, contributing to $8.7 \%$ to the overall growth. Industry and construction sector rose by $8.85 \%$, contributed to $48.6 \%$; service sector increased by $7.03 \%$, contributing to $42.7 \%$ to the overall growth [14].

GDP figures in 2018 affirmed that the policy that President Ho Chi Minh and our Party chose is correct. Our Party has clearly stated 6 principles of innovation in which the point of maintaining the socialist orientation, innovation but not changing the nature is the first principle [15]. These results made us to oppose the argument that "the innovation of our country is half-hearted and inconsistent".

The Platform on national construction in the period of transition to socialism has pointed clearly: "Going up to socialism is the aspiration of our people, the right choice of the Communist Party of Vietnam and President Ho Chi Minh, in accordance with the trend of historical development" [16]. The platform has outlined 8 characteristics of socialism that our people are building, of which the first three are: (1) Rich people, strong country, fair, democratic and civilized society; (2) owned by the people; (3) There is a high level of economic development, based on modern production forces and production relations in line with the development level of production forces. It affirmed the primacy of the socialist regime that President Ho Chi Minh laid the foundation and Our Party and people have been building. General Vo Nguyen Giap stated: "Ho Chi Minh's thought has been the soul, the victory flag of the Vietnamese revolution over the past half century. Along with Marxism-Leninism, Ho Chi Minh's thought has been the ideological foundation, a guideline for the actions of our Party and people. Ho Chi Minh's thought forever illuminates the Vietnamese revolutionary path, the path to socialism of our entire nation under the leadership of the Communist Party of Vietnam" [17].

The struggle of ideology and theories is an important content in class struggle, not only revolving around the most core issues but often associated with reality, especially changes in social life. Therefore, from its inception, Marxism-Leninism had to constantly struggle uncompromisingly with the wrong, leftist, rightist judges, hiding in all forms. 
Theories and ideology are the extremely important weapon of our Party. Over the years, it seems that we have focused a lot on economic decisions to develop a country, and we have to some extent ignored that important weapon. Firmly grasping the theoretical weapons of Marxism-Leninism and Ho Chi Minh's ideology, the Party and State will continue to lead and manage the country in a holistic, stable and right way. To ensure that the ideological struggle goes one step ahead, paving the way for revolution and contributing to the development and promotion of the Party's ideology, it is necessary to continue learning and following Ho Chi Minh's ideology, morality and style. It needs to focus on the following contents:

First, be persistent in the goal and the ideal of national independence closely link with socialism on the basis of Marxism-Leninism and Ho Chi Minh's thought, infinite loyalty to the national and class interest.

Second, strengthen to build and rectify a clean and strong Party and political system.

Third, continue to promote the will, aspirations and strength of great national unity combined with the power of the times; promoting innovation to rapidly and sustainably develop the country.

Fourth, continue to well implement Directive 05-CT/TW of the Politburo (term XII); promoting patriotic emulation movement to contribute to the successful organization of Party congress at all levels towards the XIII National Congress of the Party.

\section{Conclusion}

In short, the mistakes of the people who negate Marxism Leninism are reflected directly within the criticisms. They either misunderstand the nature of the theory or deliberately distort it with their prejudice and political aim of replacing socialist thinking, policies and goals with another theory and another social model. This purpose only benefits a certain group of people, and that group does not include the majority of people or the whole nation.

Although Marxism-Leninism was born from the social and economic conditions of the nineteenth century, but this doctrine is not outdated. It has pointed out the law of the development of human society that is the dialectical relationship between the productive forces and the relations of production.

The model of socialism in the Soviet Union and Eastern European countries collapsed, not because the theory of Marxism-Leninism was wrong. Currently, MarxismLeninism is still existing and developing in history, selected by many countries around the world and applied in socioeconomic construction of many countries including Vietnam.

The process of building and developing our country following the socialist path based on Marxism-Leninism and Ho Chi Minh's Thought has been proved correct by practical activities in history. Therefore, the choice of MarxismLeninism and Ho Chi Minh's thought as the ideological foundation and a guideline for the actions of our Party is reasonable which is the trend of the present and the future.

\section{References}

[1] Le Quy Trinh (2019). Fighting against the argument for a separation between Ho Chi Minh's ideology and MarxismLeninism. Retrieved from https:/hcma.vn/english/news/Pages/features.aspx?CateID=20 $0 \&$ ItemID $=9214$.

[2] International Conference on President Ho Chi Minh (1990). UNESCO and Vietnam Social Science Committee, Hanoi: Social science Publishing House, p. 9.

[3] Ho Chi Minh (2011). Complete Works, vol. 8, Hanoi: National Politics-The Truth Publishing House, p. 317.

[4] Ho Chi Minh (2011). Complete Works, vol. 8, Hanoi: National Politics-The Truth Publishing House, p. 257.

[5] Nguyen Van Su. Doctoral thesis: the Party led to restrain and defeat the US imperialism on the main battlefield in the South from 1965 to 1973.

[6] Vo Nguyen Giap (1991). The world has changed, but Ho Chi Minh's thought is still alive. Social Science Committee of the Municipal Committee Publishing House.

[7] Ho Chi Minh (2006). Chronicle of Biography. Vol. 2. Hanoi: National Political Publishing House, p. 287.

[8] Nguyen Ngoc Ha (2018). The textbook on Senior political theory of History of the Communist Party of Vietnam, Ha Noi: Political Theory Publishing House.

[9] Tran Minh Truong \& Pham Ngoc Anh (2018). The Textbook of Senior Political Theory on Ho Chi Minh's Thought, Hanoi: Political Theory Publishing House.

[10] Central Theoretical Council (2017). Criticism of distorted wrong views and the fight against the degradation of political thought, and expressions such as "self-evolution", "selftransformation": Ha Dang, Renunciation of Socialism is a big mistake, National Hanoi Politics - the Truth Publishing House.

[11] Dinh Xuan Ly \& Nguyen Quang Dang (2017). The textbook on Revolutionary lines of the Communist Party of Vietnam, National Politics - the Truth Publishing House.

[12] Ho Chi Minh (2011). Complete Work. Vol. 4. Ha noi: National Politics- The Truth Publishing House, p. 187.

[13] CPV (2016). Document of the 12th National Party Congress. Hanoi: National Politics-The Truth Publishing House. pp. 6061 .

[14] General Statistics Office (2018). Socio-economic situation in 2018 .

[15] Tran Nham (2006). Theoretical thinking with innovation cause, Hanoi: National Political Publishing Houise.

[16] CPV (2011). Document of the 11th National Party Congress. Hanoi: National Politics The Truth Publishing House.

[17] General Vo Nguyen Giap (2013). Ho Chi Minh's thought and the Path of Vietnamese revolution. Hanoi: National Politics Publishing House. 